\title{
MEASURING THE POTENTIAL OF ECONOMIC DEVELOPMENT OF THE SVERDLOVSK REGION BASED ON COMPARATIVE ADVANTAGES

\author{
Rogneda Groznykh $^{1}$, Natalia Davidson ${ }^{2}$, Oleg Mariev ${ }^{3,4}$, Daria Chipchagova $^{5}$, \\ Ekaterina Vasilyeva ${ }^{6}$
}

\begin{abstract}
The goal of this paper is to reveal the key industries of comparative advantage for the Sverdlovsk region in order to make conclusions about the potential of the region's economic development. We study comparative advantages of the Sverdlovsk region based on data for 85 Russian regions covering the period from 2003 to 2018. During the first stage of the research four groups of goods out of twenty-two groups were identified as those in which the Sverdlovsk region possibly has comparative advantages based on the index of revealed comparative advantages developed by Balassa and on the Lafay index. During the next stage, the existence of comparative advantages in these categories of goods was checked by comparison with the other regions of Russia. According to the results of the research a range of recommendations can be developed to foster economic growth of the Sverdlovsk region.
\end{abstract}

JEL Classification Numbers: F10, F14, O10, DOI: https://doi.org/10.12955/peb.v1.20

Keywords: revealed comparative advantage, the Balassa index, the Lafay index, Russian regions, economic development, Sverdlovsk

region

\section{Introduction}

The economic and political fluctuations and processes that have embraced the global economy in recent times have stimulated most countries of the world to reflect on their current economic policy. The Uruguay Round of the General Agreement on Tariffs and Trade (1986-1994) and creation of WTO led to more intensive international competition due to a trend of increasing interdependence and openness of the world economies.

In spite of the current tendencies of protectionism arising mainly from the events in the political sphere, the world countries continue to be interconnected. Therefore, the main aim of economic reforms of various kinds should probably be to increase the competitiveness of domestic production. This issue of public policy can be addressed by identifying and stimulating development of the most promising industries, keeping in mind the overall business environment required for their development. It is also important to take into account the heterogeneous distribution of production among cities and regions, as well as the comparative advantages in certain industries.

The concept of comparative advantage was initially proposed by David Ricardo. Comparative advantages of the countries and regions arise when goods in some industry can be produced with relatively lower opportunity costs, leading to specialization in production and export. The goal of this paper is to reveal the key industries of comparative advantage for the Sverdlovsk region. Based on these findings the conclusions about the potential of the region's economic development will be made.

In the next section we review the existing theories of comparative advantage. Then we describe the data and methodology: the approaches to revealing comparative advantages that were suggested by Balassa (1965) and by Lafay (1992). Afterwards these indicators are analyzed and calculated for the Sverdlovsk region. The Lafay index being a more accurate indicator for revealing comparative advantages (Zaghini, 2003), the ranking of the Russian regions according to this index is compiled. According to this ranking, the Sverdlovsk region occupied the leading position in production of metals

\footnotetext{
${ }^{1}$ Graduate School of Economics and Management, Ural Federal University, Yekaterinburg, Russian Federation, ronav999@gmail.com

${ }^{2}$ Graduate School of Economics and Management, Ural Federal University, Yekaterinburg, Russian Federation, natalya.davidson@gmail.com

${ }^{3}$ Graduate School of Economics and Management, Ural Federal University, Yekaterinburg, Russian Federation o.s.mariev@urfu.ru

${ }^{4}$ Institute of Economics, The Ural Branch of the Russian Academy of Sciences, Yekaterinburg, Russian

Federation

${ }^{5}$ Graduate School of Economics and Management, Ural Federal University, Yekaterinburg, Russian Federation, 1lcc1976@mail.ru

${ }^{6}$ Graduate School of Economics and Management, Ural Federal University, Yekaterinburg, Russian Federation, nikkiblac@mail.ru
} 
and metalwork in 2013-2018; comparative advantages were also found in wood and wood products, as well as in jewelry industries. In conclusion we discuss potential for the development of comparative advantages for the Sverdlovsk region.

\section{Literature Review}

It is found in the literature that firms engaged in international trade tend to be more productive and larger, and to pay higher wages, this way providing better job opportunities and contributing relatively more to economic development. Besides, international trade and firm survival are found to be positively linked (Wagner, 2019). The current specialization of Russia is not beneficial for the Russian economy; export should be diversified and efforts should be made in order to export to developed countries (Lyubimov, 2019). Moreover, modern theories of international trade make it clear that a country or region can change its comparative advantages and explain the mechanisms behind such changes. For example, comparative advantages can change due to changes in technologies and the availability of production factors. They can also change due to changes in productivity on the industry level resulting from economic openness (Melitz, 2003). Therefore, it is important to understand in which sectors of the economy there are firms that are already involved in international trade or have a potential to become exporters, in other words, to analyze the comparative advantages both on the country and regional levels.

In our analysis we rely on the international trade models explaining countries' comparative advantages. However, it is important to keep in mind that factors behind trade are not limited by comparative advantages. Other factors, such as increasing return to scale and technological spillovers can define a country's specialization (Hausmann et al., 2006).

As the models based on comparative advantages are built upon different assumptions, they suggest different reasons for comparative advantages, each focusing on a specific aspect of economic reality. These reasons contain but are not limited to differences in the countries' endowment with production factors and different levels of capital-labor ratio in the industries, different levels of production technologies in various industries, differences between the countries' economies (from the tax system to state programs designed to support and stimulate production) and institutions in the country (economic, political institutions and so on).

In theories of international trade there are three main groups of factors explaining countries' comparative advantages: (1) factors on the supply side: technological differences between countries (David Ricardo model); differences in the countries' endowment of non-specific production factors (Heckscher-Ohlin-Samuelson model); differences in the countries' endowment of specific production factors (Ricardo-Viner model); (2) factors on the demand side: differences between countries in preferences; (3) differences between countries in the type of market structure.

Considering the supply side, it is worth discussing specific factors of production, as production factors do tend to be specific, particularly over a short or medium run. Specific factors are those required only by a given industry, without a possibility of moving between industries; in other words, factors that cannot be used in an alternative way without a significant loss of their value. This concept, and later the theory of specific production factors, was first proposed by the American economists P. Samuelson (Samuelson, 1971) and R. Jones (Jones, 1971). According to the specific factor theory, the basis of international trade is the difference in relative prices of goods, which in turn are the result of different countries or regions being endowed differently with specific production factors. Within this framework, it is important, which specific factors a region possesses and can develop; the same time factors that are specific to the export sector gain from international trade.

The 2009 Nobel Prize Laureate in Economics, Oliver Williamson, introduced the concept of specific assets and their classification into four main types: the specificity of location (site) caused by low mobility of assets due to high costs; the specificity of physical factors, determined by the physical characteristics of the resource; the specificity of human capital arising from the acquisition by an employee of skills that can be applied only at a given place of work; target factors of production resulting from investments aimed at expanding existing production capacities undertaken to meet the demand of a specific buyer (Williamson, 2009). This approach is useful for our analysis of various industries of the Sverdlovsk region in the context of the available production factors, investments and the degree of the factors' mobility. 
The basic assumptions of the models mentioned above are the following: 1) there are no fundamental distortions in the economy, such as government intervention; price signals determine transactions; 2) behavior of firms and households is rational and optimizing; 3) the equilibrium of closed and open economy should be Pareto optimal. Although the assumptions of these models hold only partly in the economic reality, the major observed outcomes tend to be close to the ones described in the models. Therefore, we rely on these models as a useful background for our study.

A country's specialization in production and trade defines its economic growth (Hausmann et al., 2007). Among the examples of successful economic development, where specialization played a significant role, are South Korea, Taiwan and Singapore (Eichengreen et al., 2013). Therefore, specialization in trade deserves attention. Furthermore, countries can benefit in terms of productivity increase due to exporting (Atkin et al., 2017).

There are many alternative methods for measuring comparative advantage. In the work by James Harrigan (1997), it was proposed to evaluate the comparative advantages of industries by their shares in the country's GDP. Daniel Treffler suggested calculating the net trade volume in each factor of production by groups of countries (Treffler, 1993; 1995). Comparing these flows to the production factors endowment and taking into account differences in preferences and productivity in different countries, he empirically proved that both the "technological theory" of comparative advantages and the "theory of factor supply of countries" hold. However, this approach does not include trade costs (tariff and non-tariff barriers, transportation costs).

In our paper, we examine regional trade in final goods with the aim to understand current specialization of the region, the possibilities for development of the region's international trade and policy measures that could be useful for this. In this context it is important to take into account the existing regional specialization (Delgado et al., 2016). It is important to understand, which industries are developed in a region, and which industries have potential for development (Frenken et al., 2007). To measure the degree of the existing specialization in trade of the Sverdlovsk region, as well as its potential in the context of trade specialization, we turn to the comparative advantage indices (Garanina, 2009). In our work, we use both the index suggested by Balassa and the Lafay index, keeping in mind that the Lafay index appears to be more reliable as it is explained in the data and methodology section below.

\section{Data and Methodology}

Our study is based on data covering 85 Russian regions for the years 2003 to 2018. The database consists of 22 categories of goods including the hidden section (22). Table 1 contains basic descriptive statistics of net exports for the identified categories of goods. For calculations presented in all tables below we use data on exports and imports of the Russian Federation (Ru-Stat, 2020).

\begin{tabular}{|c|c|c|c|c|c|c|}
\hline № & Category of the good & Min & Max & Mean & Variance & Mode \\
\hline 1 & Animal products & -6.031 & 0.392 & -1.786 & 2.149 & -1.312 \\
\hline 2 & Plant Products & -18.893 & -1.6 & -7.47 & 10.97 & - \\
\hline 3 & Fats and oils & 1.16 & 5.245 & 2.893 & 1.126 & - \\
\hline 4 & Food, Beverages, Tobacco & -4 & 1.4 & -1.19 & 1.124 & -0.2 \\
\hline 5 & Mineral products & -59.78 & 13.2 & -11.02 & 214.2 & -16.1 \\
\hline 6 & Chemical industry products & -88.2 & 76.1 & -8.062 & 606.1 & 3.7 \\
\hline 7 & Plastics, rubber & -19.7 & -4.6 & -13.51 & 9.02 & -15.9 \\
\hline 8 & Leather and fur products & -2.857 & -0.076 & -0.818 & 0.31 & -0.83 \\
\hline 9 & Wood and wood products & 5.699 & 23.9 & 15.21 & 13.05 & 17 \\
\hline 10 & Books, paper, cardboard & -5.9 & 16.3 & -0.995 & 8.255 & -0.9 \\
\hline 11 & Textile & -10.15 & -2.276 & -5.94 & 3.746 & - \\
\hline 12 & Shoes, hats, umbrellas, etc. & -2.369 & -0.311 & -1.238 & 0.228 & - \\
\hline 13 & Stone, ceramic and glass products & -5.4 & 1.1 & -1.277 & 1.309 & -1.4 \\
\hline 14 & Jewelry & 0.733 & 50.67 & 23.77 & 166.8 & - \\
\hline 15 & Metals and metalwork & 156.5 & 411.9 & 281.1 & 348.3 & 260 \\
\hline 16 & Machines, equipment & -169.9 & -3.7 & -55.68 & 780.1 & - \\
\hline 17 & Transport & -30.2 & 19.1 & 0.68 & 70.87 & -1.8 \\
\hline 18 & Instruments, devices, watches & -29.7 & 54.5 & -9.93 & 92.14 & -10.4 \\
\hline 19 & Weapons and ammunition & - & - & - & - & - \\
\hline 20 & Miscellaneous manufactured goods & -11.828 & 0.5 & -5.368 & 4.579 & 0 \\
\hline
\end{tabular}




\begin{tabular}{|l|l|c|c|c|c|c|}
\hline 21 & Artworks and Antiques & -0.392 & 0.002 & $\mathbf{- 0 . 0 2 2}$ & 0.005 & 0 \\
\hline 22 & Hidden section & -65.2 & 499.5 & $\mathbf{1 5 4 . 1}$ & 17192 & - \\
\hline
\end{tabular}

Based on the data in Table 1, it can be assumed that the Sverdlovsk region will have a comparative advantage in goods $3,9,14$, and 15 , since their net export was positive for the 5 year period. However, industries with negative mean but positive and substantial maximum value, such as industry 18 (Instruments, devices, watches) are also among the industries that demonstrate potential for exporting, because we observe net export in this industry at some points in time over the years 2013-2018.

Besides, the variance shows the scatter of data, which in our case can reflect seasonality; it is especially noticeable for goods 5, 6, 14, 15, 16 and 22. Information on product 19 is not published.

Our methodology implies calculation of the index of revealed comparative advantages by Balassa (Balassa, 1965) and index of international specialization suggested by Lafay (Lafay, 1992). The indices are calculated using the following equations. Revealed comparative advantages index by Balassa:

$$
R C A_{E X}=\frac{E x_{r j} \times E x_{c}}{E x_{r} \times E x_{c j}},
$$

where $R C A_{E X}$ denotes the index of revealed comparative advantages; $E x_{r j}$-exports from the region $r$ of the good $j$ (billion US dollars); $E x_{c}$ - total exports of the country (billion US dollars); $E x_{r}$ - total exports of the region $r$ (billion US dollars); $E x_{c j}$ - exports from the country of the good $j$ (billion US dollars).

The Lafay index:

$$
L F I_{i j}=100\left(\frac{E x_{i j}-I m_{i j}}{E x_{i j}+I m_{i j}}-\frac{\sum_{j=1}^{N}\left(E x_{i j}-I m_{i j}\right)}{\sum_{j=1}^{N}\left(E x_{i j}+I m_{i j}\right)}\right) \frac{E x_{i j}+I m_{i j}}{\sum_{j=1}^{N}\left(E x_{i j}+I m_{i j}\right)},
$$

where $L F I_{i j}$ is the Lafay index; $\mathrm{N}$ - total quantity of tradable goods; $E x_{i j}, I m_{i j}$ - exports and imports of goods $j$ of the region $i$ respectively (billion US dollars).

The Lafay index is more accurate for our analysis. Firstly, it allows taking into account intra-industry trade, which is important in the modern economy. Secondly, it is resistant to macroeconomic shocks because while considering the normalized trade balance for a particular product it controls for the amount of all goods traded by a particular country (Zaghini, 2003).

\section{The Economic Complexity Ranking of Exported and Imported Goods of the Sverdlovsk Region}

In Table 2 we present the Balassa revealed comparative advantages index for the Sverdlovsk region from 2003 to 2018 .

\begin{tabular}{|l} 
Table 2: The index of revealed comparative advantages for the Sverdlovsk region, 2003-2018 \\
\hline \begin{tabular}{|c|c|c|c|c|c|c|c|c|c|c|c|c|c|c|c|c|c|c|c|c|c|c|}
\hline $\begin{array}{c}\text { Year/Number } \\
\text { of the } \\
\begin{array}{c}\text { category of } \\
\text { th good }\end{array}\end{array}$ & 1 & 2 & 3 & 4 & 5 & 6 & 7 & 8 & 9 & 10 & 11 & 12 & 13 & 14 & 15 & 16 & 17 & 18 & 19 & 20 & 21 & 22 \\
\hline 2013 & 0.10 & 0.01 & 1.35 & 0.55 & 0.07 & 0.84 & 0.44 & 0.04 & 1.80 & 0.22 & 0.49 & 0.17 & 2.33 & 1.48 & 6.84 & 1.70 & 1.38 & 1.53 & - & 0.57 & 0.00 & 1.56 \\
\hline 2014 & 0.11 & 0.01 & 1.30 & 0.49 & 0.05 & 0.90 & 0.45 & 0.09 & 1.73 & 0.21 & 0.60 & 0.24 & 2.63 & 1.74 & 6.78 & 1.33 & 1.17 & 1.56 & - & 0.70 & 0.00 & 1.68 \\
\hline 2015 & 0.09 & 0.01 & 0.96 & 0.33 & 0.04 & 0.84 & 0.35 & 0.06 & 1.19 & 0.13 & 0.27 & 0.32 & 1.70 & 2.36 & 4.98 & 0.99 & 1.58 & 1.16 & - & 0.81 & 0.00 & 1.83 \\
\hline 2016 & 0.08 & 0.01 & 0.58 & 0.27 & 0.05 & 0.43 & 0.28 & 0.05 & 0.88 & 0.20 & 0.19 & 0.21 & 1.37 & 1.54 & 4.55 & 0.84 & 0.98 & 0.72 & - & 1.04 & 0.01 & 2.19 \\
\hline 2017 & 0.12 & 0.08 & 0.69 & 0.33 & 0.07 & 0.49 & 0.35 & 0.07 & 1.20 & 0.16 & 0.27 & 0.31 & 1.63 & 1.72 & 5.41 & 0.94 & 1.18 & 0.56 & - & 0.71 & 0.04 & 1.46 \\
\hline 2018 & 0.11 & 0.13 & 0.81 & 0.26 & 0.09 & 0.55 & 0.37 & 0.08 & 1.31 & 0.42 & 0.25 & 0.16 & 1.56 & 0.26 & 5.22 & 1.24 & 0.99 & 2.93 & - & 0.81 & 0.00 & 2.09 \\
\hline Mean & 0.10 & 0.04 & 0.95 & 0.37 & 0.06 & 0.68 & 0.37 & 0.06 & 1.35 & 0.22 & 0.35 & 0.24 & 1.87 & 1.52 & 5.63 & 1.17 & 1.22 & 1.41 & - & 0.77 & 0.01 & 1.80 \\
\hline
\end{tabular} \\
\hline
\end{tabular}

The category 19 (weapons and ammunition) is excluded from further analysis because there is no open data to calculate the indices. Based on the Balassa index discussed above, the value greater than 1 shows comparative advantage. Therefore, according to the mean values of the revealed comparative advantages index (2003-2018), the following four categories of goods are identified as those in which the Sverdlovsk region may have comparative advantages: 15 (metals and metalwork); 13 (stone, ceramic and glass products); 22 (hidden section); 14 (jewelry). Industry 18 (instruments, devices, watches) and a number of other industries demonstrate comparative advantages over several years as well. 
In Table 3 the Lafay index for the Sverdlovsk region is presented; calculations cover the years from 2003 to 2018 .

Table 3: The Lafay index for the Sverdlovsk region, 2003-2018

\begin{tabular}{|c|c|c|c|c|c|c|c|c|c|c|c|c|c|c|c|c|c|c|c|c|c|c|}
\hline $\begin{array}{c}\text { Year/Numbe } \\
\text { r of the } \\
\text { category of } \\
\text { the good }\end{array}$ & 1 & 2 & 3 & 4 & 5 & 6 & 7 & 8 & 9 & 10 & 11 & 12 & 13 & 14 & 15 & 16 & 17 & 18 & 19 & 20 & 21 & 22 \\
\hline 2013 & -0.52 & -1.50 & 0.16 & -0.56 & -1.48 & -2.52 & -2.11 & -0.19 & 0.86 & -0.40 & -0.94 & -0.18 & -0.49 & 1.36 & 16.99 & -12.39 & $0.70-2.27$ & - & -1.04 & -0.01 & 7.93 \\
\hline 2014 & -0.43 & -1.27 & 0.15 & -0.35 & -2.35 & -1.33 & -2.07 & -0.12 & 0.93 & -0.31 & -0.80 & -0.20 & -0.48 & 0.62 & 16.50 & -10.93 & 1.59 & -1.80 & - & -0.86 & 0.00 & 6.67 \\
\hline 2015 & -0.26 & -1.24 & 0.11 & -0.31 & -2.96 & -3.71 & -1.99 & -0.08 & 0.79 & -0.27 & -0.77 & -0.15 & -0.42 & 2.15 & 13.47 & -12.79 & 0.37 & -1.87 & - & -0.75 & 0.00 & 11.41 \\
\hline 2016 & -0.19 & -1.09 & 0.11 & -0.50 & -3.59 & -3.29 & -2.61 & -0.08 & 0.68 & -0.25 & -0.78 & -0.22 & -0.61 & 1.82 & 9.98 & -8.05 & 0.54 & -2.16 & - & -0.70 & 0.00 & 12.08 \\
\hline 2017 & -0.25 & -0.81 & 0.17 & -0.40 & -4.42 & -2.96 & -2.40 & -0.16 & 1.14 & -0.23 & -1.01 & -0.20 & -0.51 & 2.26 & 14.92 & -7.86 & 0.03 & -1.50 & - & -0.96 & 0.00 & 5.21 \\
\hline 2018 & -0.14 & -0.72 & 0.20 & -0.23 & -4.69 & -2.97 & -2.17 & -0.10 & 1.15 & -0.05 & -0.99 & -0.18 & -0.43 & 0.20 & 12.68 & -7.19 & 0.39 & -0.65 & - & -0.79 & 0.00 & 7.47 \\
\hline
\end{tabular}

Based on the methodology described above, a positive value of the Lafay index is an indicator of comparative advantage. According to this index, the Sverdlovsk region has revealed comparative advantages in production of 15 (metals and metalwork); 14 (jewelry); 22 (hidden section). The hidden section is not included in further analysis because there is no opportunity to give any comments on this category.

Table 4: The Lafay index ranking by region of the Russian Federation in $2013-2018,9^{\text {th }}$ good (wood and wood products)

\begin{tabular}{|c|c|c|c|c|c|c|c|c|c|c|c|c|}
\hline \multicolumn{13}{|c|}{ Wood and wood products (9th category) } \\
\hline \multirow[b]{2}{*}{ 莺 } & \multicolumn{2}{|l|}{2013} & \multicolumn{2}{|l|}{2014} & \multicolumn{2}{|c|}{2015} & \multicolumn{2}{|c|}{2016} & \multicolumn{2}{|l|}{2017} & \multicolumn{2}{|l|}{2018} \\
\hline & Region & LFI & Region & LFI & Region & LFI & Region & LFI & Region & LFI & Region & LFI \\
\hline 1 & $\begin{array}{c}\text { Jewish } \\
\text { Autonomous } \\
\text { Region }\end{array}$ & 43.56 & $\begin{array}{c}\text { Jewish } \\
\text { Autonomous } \\
\text { Region }\end{array}$ & 45.80 & $\begin{array}{r}\text { Khanty-Mansi } \\
\text { Autonomous } \\
\text { Area - Yugra }\end{array}$ & 47.35 & $\begin{array}{c}\text { Jewish } \\
\text { Autonomous } \\
\text { Region }\end{array}$ & $\begin{array}{c}49.5 \\
4\end{array}$ & $\begin{array}{c}\text { Jewish } \\
\text { Autonomous } \\
\text { Region }\end{array}$ & $\begin{array}{c}49.7 \\
3\end{array}$ & $\begin{array}{c}\text { Jewish } \\
\text { Autonomous } \\
\text { Region }\end{array}$ & $\begin{array}{c}49.3 \\
5\end{array}$ \\
\hline 2 & $\begin{array}{l}\text { Astrakhan } \\
\text { Region }\end{array}$ & 43.13 & $\begin{array}{c}\text { Trans-Baikal } \\
\text { Territory }\end{array}$ & 41.05 & \begin{tabular}{|c|} 
Jewish \\
Autonomous \\
Region \\
\end{tabular} & 45.03 & \begin{tabular}{|r|} 
Khanty-Mansi \\
Autonomous \\
Area - Yugra \\
\end{tabular} & $\begin{array}{c}43.9 \\
8\end{array}$ & $\begin{array}{c}\text { Trans-Baikal } \\
\text { Territory }\end{array}$ & $\begin{array}{c}41.9 \\
1\end{array}$ & Amur Region & $\begin{array}{c}49.2 \\
7\end{array}$ \\
\hline 3 & Amur Region & 39.20 & $\begin{array}{c}\text { Astrakhan } \\
\text { Region }\end{array}$ & 40.76 & $\begin{array}{c}\text { Trans-Baikal } \\
\text { Territory }\end{array}$ & 38.69 & Amur Region & $\begin{array}{c}39.5 \\
9\end{array}$ & $\begin{array}{c}\text { Khanty- } \\
\text { Mansi } \\
\text { Autonomous } \\
\text { Area - Yugra }\end{array}$ & $\begin{array}{c}41.2 \\
2\end{array}$ & $\begin{array}{l}\text { Khanty-Mansi } \\
\text { Autonomous } \\
\text { Area - Yugra }\end{array}$ & $\begin{array}{c}48.6 \\
9\end{array}$ \\
\hline 4 & Republic of Altai & i 38.32 & Amur Region & 35.49 & Amur Region & 33.24 & $\begin{array}{c}\text { Trans-Baikal } \\
\text { Territory }\end{array}$ & $\begin{array}{c}35.8 \\
4\end{array}$ & $\begin{array}{l}\text { Tyumen } \\
\text { Region }\end{array}$ & $\begin{array}{c}39.9 \\
3\end{array}$ & $\begin{array}{l}\text { Vladimir } \\
\text { Region }\end{array}$ & $\begin{array}{c}37.5 \\
1\end{array}$ \\
\hline 5 & $\begin{array}{l}\text { Leningrad } \\
\text { Region }\end{array}$ & 25.77 & Tyumen Region & 32.82 & $\begin{array}{c}\text { Primorye } \\
\text { Territory }\end{array}$ & 31.21 & Vladimir Region & $\begin{array}{c}33.1 \\
3\end{array}$ & $\begin{array}{l}\text { Astrakhan } \\
\text { Region }\end{array}$ & $\begin{array}{c}35.8 \\
3\end{array}$ & $\begin{array}{l}\text { Karachayevo- } \\
\text { Circassian } \\
\text { Republic }\end{array}$ & $\begin{array}{c}34.1 \\
3\end{array}$ \\
\hline 81 & Moscow & -3.65 & Ivanovo Region & -9.30 & $\begin{array}{c}\text { Kabardino- } \\
\text { Balkarian } \\
\text { Republic }\end{array}$ & -5.08 & $\begin{array}{c}\text { Kabardino- } \\
\text { Balkarian } \\
\text { Republic } \\
\end{array}$ & -2.20 & $\begin{array}{l}\text { Kursk } \\
\text { Region }\end{array}$ & -2.66 & Kursk Region & -1.70 \\
\hline 82 & $\begin{array}{l}\text { Nizhny } \\
\text { Novgorod } \\
\text { Region } \\
\end{array}$ & -4.45 & Penza Region & -9.68 & Ivanovo Region & -7.85 & $\begin{array}{r}\text { Krasnodar } \\
\text { Territory }\end{array}$ & -2.20 & $\begin{array}{l}\text { Smolensk } \\
\text { Region }\end{array}$ & -2.72 & $\begin{array}{l}\text { Republic of } \\
\text { Ingushetia }\end{array}$ & -1.79 \\
\hline 83 & Pskov Region & -7.60 & $\begin{array}{c}\text { Smolensk } \\
\text { Region }\end{array}$ & -10.17 & $\begin{array}{c}\text { Smolensk } \\
\text { Region }\end{array}$ & -9.93 & $\begin{array}{r}\text { Smolensk } \\
\text { Region }\end{array}$ & -3.87 & $\begin{array}{l}\text { Yamal- } \\
\text { Nenets } \\
\text { Autonomous } \\
\text { Area }\end{array}$ & -6.03 & $\begin{array}{c}\text { Republic of } \\
\text { North Ossetia - } \\
\text { Alania }\end{array}$ & -2.36 \\
\hline 84 & $\begin{array}{c}\text { Smolensk } \\
\text { Region }\end{array}$ & -12.28 & $\begin{array}{c}\text { Kamchatka } \\
\text { Territory }\end{array}$ & -20.39 & Sevastopol & $\mid-19.51$ & Ivanovo Region & -7.32 & $\begin{array}{c}\text { Republic of } \\
\text { Crimea }\end{array}$ & -7.23 & $\begin{array}{l}\text { Republic of } \\
\text { Crimea }\end{array}$ & -5.48 \\
\hline 85 & Penza Region & -16.57 & $\begin{array}{l}\text { Republic of } \\
\text { Crimea }\end{array}$ & -34.02 & $\begin{array}{l}\text { Republic of } \\
\text { Crimea }\end{array}$ & -20.55 & $\begin{array}{c}\begin{array}{c}\text { Yamal-Nenets } \\
\text { Autonomous } \\
\text { Area }\end{array} \\
\end{array}$ & -9.97 & Sevastopol & $\begin{array}{c}- \\
19.4 \\
2\end{array}$ & $\begin{array}{c}\text { Yamal-Nenets } \\
\text { Autonomous } \\
\text { Area } \\
\end{array}$ & $\begin{array}{c}- \\
20.7 \\
9\end{array}$ \\
\hline * & $\begin{array}{l}\text { Sverdlovsk } \\
\text { Region *(48) }\end{array}$ & 0.86 & $\begin{array}{l}\text { Sverdlovsk } \\
\text { Region *(49) }\end{array}$ & 0.93 & $\begin{array}{l}\text { Sverdlovsk } \\
\text { Region } *(51)\end{array}$ & 0.79 & $\begin{array}{l}\text { Sverdlovsk } \\
\text { Region *(52) }\end{array}$ & 0.68 & $\begin{array}{l}\text { Sverdlovsk } \\
\text { Region } \\
*(53)\end{array}$ & 1.14 & $\begin{array}{l}\text { Sverdlovsk } \\
\text { Region *(53) }\end{array}$ & 1.15 \\
\hline
\end{tabular}

During the analyzed period the Jewish Autonomous region possessed a comparative advantage in wood production, except for the year 2015. The Sverdlovsk region ranked the $48^{\text {th }}$ in 2013 , however, by 2018 , the comparative advantage of the Sverdlovsk region decreased (the Sverdlovsk region was on the 53rd place in 2018).

There is ambiguous dynamics of the Lafay index, calculated in the Sverdlovsk region for the good 14. By 2018 the Sverdlovsk region fell by 3 positions in the ranking, despite the increase of the comparative advantage in 2017 by 2 lines of the ranking in comparison with 2016. 
The Sverdlovsk region has a revealed comparative advantage in the production of metals and metalwork among the other regions of the Russian Federation. During 2013-2018 the Sverdlovsk region belonged to one of three regions with the highest Lafay index in this good. The highest value of this index was observed in 2013, during the period before the crisis of 2014. Since 2013 the Sverdlovsk region lost its leading position in this ranking.

Table 5: The Lafay index ranking by region of the Russian Federation in $2013-2018,14^{\text {th }}$ good (jewelry)

\begin{tabular}{|c|c|c|c|c|c|c|c|c|c|c|c|c|}
\hline \multicolumn{13}{|c|}{ Jewelry (14th category) } \\
\hline \multirow{2}{*}{ 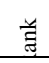 } & \multicolumn{2}{|l|}{2013} & \multicolumn{2}{|l|}{2014} & \multicolumn{2}{|c|}{2015} & \multicolumn{2}{|l|}{2016} & \multicolumn{2}{|l|}{2017} & \multicolumn{2}{|l|}{2018} \\
\hline & Region & LFI & Region & LFI & Region & LFI & Region & LFI & Region & LFI & Region & LFI \\
\hline 1 & Moscow & 35.94 & $\begin{array}{l}\text { Stavropol } \\
\text { Territory } \\
\end{array}$ & $\begin{array}{c}34.2 \\
9 \\
\end{array}$ & $\begin{array}{l}\text { Stavropol } \\
\text { Territory }\end{array}$ & 36.34 & $\begin{array}{l}\text { Stavropol } \\
\text { Territory }\end{array}$ & 42.55 & $\begin{array}{l}\text { Stavropol } \\
\text { Territory }\end{array}$ & 38.20 & $\begin{array}{c}\text { Magadan } \\
\text { Region }\end{array}$ & 42.41 \\
\hline 2 & $\begin{array}{c}\text { Magadan } \\
\text { Region }\end{array}$ & 34.40 & Moscow & $\begin{array}{r}30.4 \\
6 \\
\end{array}$ & Moscow & 34.91 & Moscow & 32.33 & Moscow & 31.60 & Moscow & 31.92 \\
\hline 3 & $\begin{array}{l}\text { Stavropol } \\
\text { Territory }\end{array}$ & 28.36 & $\begin{array}{l}\text { Smolensk } \\
\text { Region }\end{array}$ & $\begin{array}{c}24.3 \\
7\end{array}$ & $\begin{array}{l}\text { Smolensk } \\
\text { Region }\end{array}$ & 18.89 & $\begin{array}{l}\text { Magadan } \\
\text { Region }\end{array}$ & 26.10 & $\begin{array}{c}\text { Magadan } \\
\text { Region }\end{array}$ & 24.58 & $\begin{array}{l}\text { Stavropol } \\
\text { Territory }\end{array}$ & 18.64 \\
\hline 4 & $\begin{array}{c}\text { Smolensk } \\
\text { Region }\end{array}$ & 22.52 & $\begin{array}{c}\text { Novosibirsk } \\
\text { Region }\end{array}$ & $\begin{array}{c}13.2 \\
0\end{array}$ & $\begin{array}{l}\text { Magadan } \\
\text { Region }\end{array}$ & 15.21 & $\begin{array}{c}\text { Smolensk } \\
\text { Region }\end{array}$ & 16.02 & $\begin{array}{c}\text { Smolensk } \\
\text { Region }\end{array}$ & 17.69 & $\begin{array}{c}\text { Smolensk } \\
\text { Region }\end{array}$ & 16.75 \\
\hline 5 & $\begin{array}{c}\text { St. } \\
\text { Petersburg } \\
\end{array}$ & 11.92 & $\begin{array}{c}\text { St. } \\
\text { Petersburg } \\
\end{array}$ & \begin{tabular}{|c|}
13.0 \\
4 \\
\end{tabular} & $\begin{array}{c}\text { St. } \\
\text { Petersburg } \\
\end{array}$ & 7.72 & $\begin{array}{c}\text { Yaroslavl } \\
\text { Region }\end{array}$ & 10.37 & $\begin{array}{c}\text { St. } \\
\text { Petersburg } \\
\end{array}$ & 17.12 & St. Petersburg & 5.43 \\
\hline 81 & $\begin{array}{l}\text { Ryazan } \\
\text { Region }\end{array}$ & -0.51 & $\begin{array}{c}\text { Krasnoyarsk } \\
\text { Territory }\end{array}$ & $\begin{array}{c}- \\
1.1 \\
7 \\
\end{array}$ & $\begin{array}{l}\text { Kostroma } \\
\text { Region }\end{array}$ & -2.78 & $\begin{array}{l}\text { Chuvash } \\
\text { Republic }\end{array}$ & -0.96 & $\begin{array}{l}\text { Chuvash } \\
\text { Republic }\end{array}$ & -1.08 & $\begin{array}{c}\text { Republic of } \\
\text { Adygeya }\end{array}$ & -1.15 \\
\hline 82 & $\begin{array}{c}\text { Krasnoyarsk } \\
\text { Territory }\end{array}$ & -0.95 & $\begin{array}{l}\text { Kostroma } \\
\text { Region }\end{array}$ & $\begin{array}{c}- \\
3.4 \\
4\end{array}$ & $\begin{array}{c}\text { Krasnoyarsk } \\
\text { Territory }\end{array}$ & -4.37 & $\begin{array}{c}\text { Krasnoyarsk } \\
\text { Territory }\end{array}$ & -1.99 & $\begin{array}{c}\text { Krasnoyarsk } \\
\text { Territory }\end{array}$ & -1.58 & $\begin{array}{c}\text { Krasnoyarsk } \\
\text { Territory }\end{array}$ & -1.97 \\
\hline 83 & $\begin{array}{l}\text { Kostroma } \\
\text { Region }\end{array}$ & -2.33 & $\begin{array}{c}\text { Kabardino- } \\
\text { Balkarian } \\
\text { Republic } \\
\end{array}$ & $\begin{array}{c}- \\
4.0 \\
9\end{array}$ & $\begin{array}{c}\text { Kabardino- } \\
\text { Balkarian } \\
\text { Republic } \\
\end{array}$ & -6.20 & $\begin{array}{c}\text { Kabardino- } \\
\text { Balkarian } \\
\text { Republic } \\
\end{array}$ & -3.34 & $\begin{array}{c}\text { Kabardino- } \\
\text { Balkarian } \\
\text { Republic } \\
\end{array}$ & -5.18 & $\begin{array}{c}\text { Yamal-Nenets } \\
\text { Autonomous } \\
\text { Area }\end{array}$ & -2.14 \\
\hline 84 & $\begin{array}{c}\text { Kabardino- } \\
\text { Balkarian } \\
\text { Republic } \\
\end{array}$ & -7.12 & $\begin{array}{l}\text { Primorye } \\
\text { Territory }\end{array}$ & $\begin{array}{l}- \\
19 . \\
24\end{array}$ & $\begin{array}{l}\text { Primorye } \\
\text { Territory }\end{array}$ & -23.19 & $\begin{array}{l}\text { Kostroma } \\
\text { Region }\end{array}$ & -5.95 & $\begin{array}{l}\text { Kostroma } \\
\text { Region }\end{array}$ & -10.59 & $\begin{array}{c}\text { Kabardino- } \\
\text { Balkarian } \\
\text { Republic } \\
\end{array}$ & -4.66 \\
\hline 85 & $\begin{array}{l}\text { Primorye } \\
\text { Territory }\end{array}$ & -19.78 & Amur Region & $\begin{array}{l}- \\
29 . \\
71\end{array}$ & Amur Region & -31.70 & Amur Region & -21.06 & $\begin{array}{l}\text { Primorye } \\
\text { Territory }\end{array}$ & -22.63 & $\begin{array}{l}\text { Kostroma } \\
\text { Region }\end{array}$ & -11.10 \\
\hline * & $\begin{array}{c}\text { Sverdlovsk } \\
\text { Region } *(26)\end{array}$ & 1.36 & $\begin{array}{c}\text { Sverdlovsk } \\
\text { Region } *(28)\end{array}$ & 0.62 & $\begin{array}{c}\text { Sverdlovsk } \\
\text { Region } *(27)\end{array}$ & 2.15 & $\begin{array}{c}\text { Sverdlovsk } \\
\text { Region } *(26)\end{array}$ & 1.82 & $\begin{array}{c}\text { Sverdlovsk } \\
\text { Region } *(24)\end{array}$ & 2.26 & $\begin{array}{c}\text { Sverdlovsk } \\
\text { Region *(29) }\end{array}$ & 0.20 \\
\hline
\end{tabular}

Table 6: The Lafay index ranking by region of the Russian Federation in $2013-2018,15^{\text {th }}$ good (metals and metalwork)

\begin{tabular}{|c|c|c|c|c|c|c|c|c|c|c|c|c|}
\hline \multicolumn{13}{|c|}{ Metals and metalwork (15th category) } \\
\hline \multirow{2}{*}{$\pi$} & \multicolumn{2}{|l|}{2013} & \multicolumn{2}{|l|}{2014} & \multicolumn{2}{|c|}{\begin{tabular}{|l|l|}
2015 \\
\end{tabular}} & \multicolumn{2}{|c|}{2016} & \multicolumn{2}{|l|}{2017} & \multicolumn{2}{|l|}{2018} \\
\hline & Region & LFI & Region & LFI & Region & LFI & Region & LFI & Region & LFI & Region & LFI \\
\hline 1 & $\begin{array}{c}\text { Sverdlovsk } \\
\text { Region }\end{array}$ & 16.99 & $\begin{array}{c}\text { Republic of } \\
\text { Crimea }\end{array}$ & $\begin{array}{c}34.1 \\
8\end{array}$ & $\begin{array}{c}\text { Republic of } \\
\text { Crimea }\end{array}$ & $\begin{array}{c}20.7 \\
9\end{array}$ & $\begin{array}{c}\text { Republic of } \\
\text { Crimea }\end{array}$ & 27.30 & Sevastopol & 19.42 & Sevastopol & 30.22 \\
\hline 2 & Penza Region & 16.69 & $\begin{array}{c}\text { Kamchatka } \\
\text { Territory }\end{array}$ & 20.34 & Sevastopol & 19.51 & $\begin{array}{c}\text { Sverdlovsk } \\
\text { Region }\end{array}$ & 9.98 & $\begin{array}{l}\text { Sverdlovsk } \\
\text { Region }\end{array}$ & 14.92 & $\begin{array}{c}\text { Yamal-Nenets } \\
\text { Autonomous } \\
\text { Area }\end{array}$ & 22.93 \\
\hline 3 & $\begin{array}{c}\text { Kabardino- } \\
\text { Balkarian } \\
\text { Republic }\end{array}$ & 8.66 & $\begin{array}{l}\text { Sverdlovsk } \\
\text { Region }\end{array}$ & 16.50 & $\begin{array}{l}\text { Sverdlovsk } \\
\text { Region }\end{array}$ & 13.47 & $\begin{array}{c}\text { Yamal-Nenets } \\
\text { Autonomous } \\
\text { Area }\end{array}$ & 9.97 & $\begin{array}{c}\text { Republic of } \\
\text { Crimea }\end{array}$ & 7.23 & $\begin{array}{c}\text { Sverdlovsk } \\
\text { Region }\end{array}$ & 12.68 \\
\hline 4 & Pskov Region & 7.67 & Penza Region & 9.85 & $\begin{array}{c}\text { Kabardino- } \\
\text { Balkarian } \\
\text { Republic }\end{array}$ & 11.28 & $\begin{array}{c}\text { Kabardino- } \\
\text { Balkarian } \\
\text { Republic }\end{array}$ & 5.54 & $\begin{array}{c}\text { Yamal-Nenets } \\
\text { Autonomous } \\
\text { Area }\end{array}$ & 6.03 & $\begin{array}{c}\text { Republic of } \\
\text { Crimea }\end{array}$ & 5.49 \\
\hline 5 & $\begin{array}{c}\text { Nizhny } \\
\text { Novgorod } \\
\text { Region }\end{array}$ & 3.72 & Sevastopol & 8.71 & $\begin{array}{r}\text { Ivanovo } \\
\text { Region }\end{array}$ & 7.03 & $\begin{array}{l}\text { Krasnodar } \\
\text { Territory }\end{array}$ & 2.29 & Kursk Region & 2.66 & $\begin{array}{c}\text { Republic of } \\
\text { North Ossetia - } \\
\text { Alania }\end{array}$ & 2.36 \\
\hline 81 & $\begin{array}{r}\text { Magadan } \\
\text { Region }\end{array}$ & -33.94 & $\begin{array}{l}\text { Stavropol } \\
\text { Territory }\end{array}$ & -31.43 & $\begin{array}{r}\text { Vladimir } \\
\text { Region }\end{array}$ & -33.30 & Moscow & -30.52 & $\begin{array}{c}\text { Stavropol } \\
\text { Territory }\end{array}$ & -37.63 & $\begin{array}{c}\text { Karachayevo- } \\
\text { Circassian } \\
\text { Republic }\end{array}$ & -34.13 \\
\hline 82 & $\begin{array}{c}\text { Republic of } \\
\text { Altai }\end{array}$ & -38.32 & $\begin{array}{c}\text { Tyumen } \\
\text { Region }\end{array}$ & -32.82 & $\begin{array}{c}\text { Stavropol } \\
\text { Territory } \\
\end{array}$ & -35.02 & $\begin{array}{c}\text { Trans-Baikal } \\
\text { Territory }\end{array}$ & -35.74 & Vladimir Region & -39.81 & Vladimir Region & -41.51 \\
\hline 83 & Amur Region & -39.22 & $\begin{array}{r}\text { Vladimir } \\
\text { Region } \\
\end{array}$ & -33.68 & \begin{tabular}{|c|} 
Trans-Baikal \\
Territory
\end{tabular} & -38.69 & Vladimir Region & -35.86 & Tyumen Region & -39.92 & Magadan Region & -42.28 \\
\hline 84 & $\begin{array}{c}\text { Astrakhan } \\
\text { Region }\end{array}$ & -43.13 & $\begin{array}{c}\text { Astrakhan } \\
\text { Region }\end{array}$ & -40.76 & $\begin{array}{c}\text { Jewish } \\
\text { Autonomous } \\
\text { Region }\end{array}$ & -45.03 & $\begin{array}{l}\text { Stavropol } \\
\text { Territory }\end{array}$ & -42.03 & $\begin{array}{c}\text { Khanty-Mansi } \\
\text { Autonomous } \\
\text { Area - Yugra }\end{array}$ & -41.22 & $\begin{array}{c}\text { Khanty-Mansi } \\
\text { Autonomous } \\
\text { Area - Yugra }\end{array}$ & -48.69 \\
\hline 85 & $\begin{array}{c}\text { Jewish } \\
\text { Autonomous } \\
\text { Region } \\
\end{array}$ & -43.55 & $\begin{array}{c}\text { Trans-Baikal } \\
\text { Territory }\end{array}$ & -41.60 & $\begin{array}{r}\text { Khanty-Mansi } \\
\text { Autonomous } \\
\text { Area - Yugra } \\
\end{array}$ & -47.35 & $\begin{array}{c}\text { Khanty-Mansi } \\
\text { Autonomous } \\
\text { Area - Yugra } \\
\end{array}$ & -43.99 & $\begin{array}{c}\text { Trans-Baikal } \\
\text { Territory }\end{array}$ & -41.76 & Amur Region & -49.26 \\
\hline
\end{tabular}

Source: Authors

\section{Discussion}

The existing comparative advantages of the Sverdlovsk region presented in Table 3 above could be explained to a large extent by resource endowment, while the available technologies also play an 
important role. The metallurgical industry is the basis of the economy of the Sverdlovsk region. Besides, in 2010-2015 the Sverdlovsk region was one of the ten largest gold mining regions in Russia. Yet, in 2016, the region fell to the 11th place. It is predicted that reserves of platinum and gold will be exhausted within 15 years in the Sverdlovsk region. Investment is carried out to search for new deposits. Besides natural resources, the Sverdlovsk region has also an industrial structure with potential for diversification, and substantial research and human capital capacity.

According to the website devoted to the foreign economic activity of the Sverdlovsk region, metals and metalwork make up more than half of the region's exports: $56 \%$ in $2017,51 \%$ in 2018 respectively (Ru-Stat, 2020). In 2018, export of metals and metallurgical products increased compared to 2017 , for instance, the export of ferrous metals increased by $11 \%$, export of products from ferrous metals increased by $34 \%$, the export of aluminum and products from aluminum increased by $7 \%$, and the export of copper and products from copper increased by 3\% (Ru-Stat, 2020). Thus, transition of the Sverdlovsk region to the third place in the Lafay index ranking in 2018 occurred due to development of the comparative advantages of the Yamal-Nenets Autonomous Area and of Sevastopol (for Sevastopol there was an increase in output by $21.7 \%$ in 2018 compared to 2017, while in the Sverdlovsk region the increase was $12.1 \%$ ).

\section{Conclusion}

In this paper we concentrated our attention on one of the Russian regions, the Sverdlovsk region; we analyzed its leading industries and potential for development of various industries. According to the results of our study, the Sverdlovsk region has the comparative advantage in production of metals and metalwork, wood and wood products, and jewelry. While specialization in the goods of current comparative advantages provides jobs for qualified personnel, creates demand for research and allows the region to gain from trade, it is also important to develop the industries that have smaller impact on environment and express stronger demand for highly qualified labor force. In fact, since the times of the planned economy, the Sverdlovsk region has and retains a tradition of higher education in the field of engineering, and since transition towards market economy it is developing education in the fields of economics, management and other areas important for the modern enterprises. Therefore, there is potentially an educational base for the high value-added industries which in their turn would further stimulate economic development.

As for the policy recommendations arising from this research, on one hand, it is worth facilitating improvement of technologies in the industries of the current comparative advantage, together with development of the industries along the value chain, and to help firms in their effort to export focusing on the developed economies. Sustainable development issues such as environmental protection should be taken into account. On the other hand, it is important to diversify export by facilitating production in the other potentially promising industries.

Limitations of this research and, therefore, the opportunities for further research are the following. Firstly, attention should be paid to the consequences of economic sanctions for the industries under consideration. In order to do this, a larger time span should be analyzed. Secondly, more industries should be studied to better account for the scope of potential opportunities for development. Thirdly, more detail concerning the related industries should be considered.

Another relevant issue for further research is the analysis of the factors important for development and change of the regional comparative advantage towards high tech manufacturing and services. It can be assumed that they are institutions, infrastructure, taxation and various aspects of human capital. It is also essential to analyze and to take into account the impact of all industries of the revealed comparative advantage on the environment, on the labor market and on the regional economic development.

\section{Acknowledgments}

Research was supported by the Russian Foundation for Basic Research (RFBR), grant No 18-01001190 "Models for analysis of the factors of innovative development and comparative advantages in the Russian economy".

\section{References}

Atkin, D., Khandelwal, A. K., Osman, A. (2017). Exporting and firm performance: evidence from a randomized experiment. The Quarterly Journal of Economics, 132(2), 551-615. 
Balassa, B. (1965). Trade liberalisation and revealed comparative advantage. The Manchester School of Economic and Social Studies, 33, 99-123.

Delgado, M., Porter, M. E., Stern, S. (2016). Defining clusters of related industries. Journal of Economic Geography, 16(1), $1-38$.

Eichengreen, B., Park, D., Shin, K (2013). Growth slowdown redux: New evidence on the middle-income trap. NBER Working Paper, 18673.

Frenken, K., Van Oort, F.G., Verburg, T. (2007). Related variety, unrelated variety, and regional economic growth. Regional Studies, 41 (5), 685-97.

Garanina, O. (2009). What beyond oil and gas? Russian trade specialisation in manufactures. Post-communist economies, 21(1), 1-29, https://doi.org/10.1080/14631370802663596

Jones, R. A. (1971). Three-factor model in theory, trade, and history. trade, balance of payments and growth: Essays in honor of C.P. Kindleberger, Amsterdam, 3-20.

Harrigan J. (1997). Cross-country comparisons of industry total factor productivity: theory and evidence. Federal Reserve Bank of New York.

Hausmann, R., Hwang, J. \& Rodrik, D. (2007). What you export matters. Journal of Economic Growth, 12, 1-25 https://doi.org/10.1007/s10887-006-9009-4

Lafay, G. (1992). The measurement of revealed comparative advantages, International Trade Modeling, London: Chapman and Hill, 209-234.

Lyubimov, I. (2019). Russia's diversification prospects. Russian Journal of Economics, 5, 177-198

https://doi.org/10.32609/j.ruje.5.34753

Melitz, M. (2003) The impact of trade on intra-industry reallocations and aggregate industry productivity. Econometrica, 71, 1695-1725. https://doi.org/10.1111/1468-0262.00467/

Ru-Stat (2020). Exports and imports of the Russian Federation. https://ru-stat.com/

Samuelson, P. (1971). Ohlin was right. Swedish Journal of Economics, 73, 365-384. https://doi.org/10.2307/3439219

Trefler, D. (1995). The case of the missing trade and other mysteries. American Economics Review, 85(5), 1029-1046.

Trefler, D. (1993). International factor price differences: Leontief was right! Journal of Political Economy, 101(6), 961-987.

Wagner, J. (2019). Effect of international activity on firm performance. IZA World of Labor, 47v2.

https://doi.org/10.15185/izawol.47.v2

Williamson, O. (2009). Transaction cost economics: the natural progression. Nobel Prize lecture, December 8, 2009. https://www.nobelprize.org/uploads/2018/06/williamson_lecture.pdf

Zaghini, A. (2003) Trade advantages and specialization dynamics in acceding countries. European Central Bank Working paper 249 . https://www.ecb.europa.eu/pub/pdf/scpwps/ecbwp249.pdf 